\title{
Differential effects of TGF- $\beta 1$ and FGF-2 on SDF-1 $\alpha$ expression in human periodontal ligament cells derived from deciduous teeth in vitro
}

\author{
TOMOKAZU HASEGAWA ${ }^{1,2}$, NAOYUKI CHOSA $^{3}$, TAKEYOSHI ASAKAWA ${ }^{2}$, YOSHITAKA YOSHIMURA ${ }^{4}$, \\ YURI FUJIHARA $^{1}$, TAKAMASA KITAMURA ${ }^{5}$, MITSURO TANAKA $^{2}$, AKIRA ISHISAKI $^{3}$ and MASATO MITOME ${ }^{1,5}$ \\ ${ }^{1}$ Department of Pediatric Dentistry, Tokushima University Hospital, Tokushima 770-8504; \\ Departments of ${ }^{2}$ Pediatric Dentistry, ${ }^{3}$ Oral Biochemistry, School of Dentistry, Iwate Medical University, \\ Morioka 020-8505; ${ }^{4}$ Department of Molecular Cell Pharmacology, Division of Oral Pathological Science, \\ Hokkaido University Graduate School of Dental Medicine, Sapporo 060-8586; ${ }^{5}$ Department of Pediatric Dentistry, \\ Institute of Health Biosciences, University of Tokushima Graduate School, Tokushima 770-8504, Japan
}

Received December 29, 2011; Accepted February 2, 2012

DOI: $10.3892 / \mathrm{ijmm} .2012 .957$

\begin{abstract}
Stromal cell-derived factor (SDF)-1 $\alpha$ has been reported to play a crucial role in stem cell homing and recruitment to injured sites. However, no information is available about its role in periodontal tissues. The aim of this in vitro study was to investigate the effects of basic fibroblast growth factor (FGF-2) and transforming growth factor (TGF)- $\beta 1$ on SDF-1 $\alpha$ expression in immortalized periodontal ligament (PDL) cells derived from deciduous teeth (SH9 cells). Realtime PCR and western blot analyses showed that SDF-1 $\alpha$ mRNA expression in SH9 cells was markedly inhibited by FGF-2 treatment for 48 h. SU5402, which directly interacts with the catalytic domain of the FGF receptor 1 (FGFR1) and suppresses its phosphorylation, inhibited the FGF-2-related decrease in SDF-1 $\alpha$ expression. These results suggest that FGF-2 signaling via the FGFR1 pathway inhibits SDF- $1 \alpha$ expression. Conversely, SDF-1 $\alpha$ expression in SH9 cells was increased by TGF- $\beta 1$ treatment for $12 \mathrm{~h}$. Western blot analysis showed that this treatment induced Smad2/3 phosphorylation. A time-course experiment showed that SDF- $1 \alpha$ expression levels reached a maximum $12 \mathrm{~h}$ after the TGF- $\beta 1$ treatment and returned to basal levels by $48 \mathrm{~h}$. Real-time PCR analysis showed that Smad7 mRNA expression peaked by $6 \mathrm{~h}$ after TGF- $\beta 1$ treatment. Since Smad7 siRNA downregulated Smad7 expression by approximately 2.5 -fold compared with the negative control siRNA, the induction of SDF-1 $\alpha$ expression was prolonged. Furthermore, treatment of SH9 cells with
\end{abstract}

Correspondence to: Dr Tomokazu Hasegawa, Department of Pediatric Dentistry, Tokushima University Hospital, 3-18-15 Kuramoto, Tokushima 770-8504, Japan

E-mail: hasegawa@dent.tokushima-u.ac.jp

Key words: FGF-2, TGF- $\beta 1$, periodontal ligament, deciduous tooth, SDF-1 $\alpha$
TGF- $\beta 1$ for $12 \mathrm{~h}$ induced transwell migration of UE7T-13 cells, which are mesenchymal stem cells derived from human bone marrow. Therefore, SDF-1 $\alpha$ may play an important role in stem and progenitor cell recruitment and homing to injured sites in the periodontal ligament, and regulation of SDF- $1 \alpha$ expression may be a useful tool in cell-based therapy for periodontal tissue regeneration.

\section{Introduction}

The periodontal ligament (PDL) is located between the tooth root and the alveolar bone (1). It comprises a heterogeneous cell population that includes fibroblasts, cementoblasts, osteoblasts, endothelial cells, epithelial cell rests of Malassez, osteoclasts, and progenitor or stem cells (2). The PDL has an important role not only in supporting the tooth but also in contributing to tooth nutrition, homeostasis, and tissue repair $(3,4)$. In vitro studies have demonstrated that PDL cells can differentiate into cementoblastic or adipogenic cells (5). Therefore, the PDL probably contains pluripotent progenitor cells or putative stem cells. These cells can migrate to sites of injury, differentiate, and regenerate periodontal tissues. However, the detailed mechanism of stem and progenitor cell migration in the PDL has yet to be fully understood.

Stromal cell-derived factor (SDF)- $1 \alpha$ (or CXCL12) is an $\alpha$-chemokine that strongly chemoattracts mesenchymal stem cells (MSCs) and endothelial progenitor cells (EPCs) through interaction with its unique receptor, CXCR4 (6). This ligandreceptor pair plays a crucial role in the mobilization, migration, homing, proliferation, and differentiation of MSCs and EPCs (6-9). In adults, tissue repair and regeneration following injury are thought to involve the selective recruitment of circulating or resident stem cell populations. The importance of SDF-1 $\alpha$ in stem and progenitor cell recruitment is evident by the fact that its expression in injured tissue correlates with the recruitment of adult stem cells and tissue regeneration (6-9). Therefore, while the role of SDF-1 $\alpha$ in coordinating tissue repair has been established, its role in the PDL remains to be elucidated. 
At present, bioactive soluble factors such as cytokines and growth factors are being evaluated for clinical use in the regeneration of periodontal tissue damaged or lost due to periodontitis. Of these factors, both the basic fibroblast growth factor (FGF-2) and the transforming growth factor (TGF)- $\beta 1$ are multifunctional growth factors that have various effects, including the induction of proliferation and differentiation of a wide range of mesodermal and neuroectodermal cells $(10,11)$. However, their effects on SDF-1 $\alpha$ expression in PDL cells are currently unknown.

SH9 cells are immortalized human PDL cells derived from deciduous teeth by the induction of the human telomerase reverse transcriptase (hTERT) gene (12). In this in vitro study, we used SH9 cells to investigate the effects of FGF-2 and TGF- $\beta 1$ on SDF- $1 \alpha$ expression in PDL cells.

\section{Materials and methods}

Cell culture. SH9 human PDL cells were maintained in $\alpha$-modified minimum essential medium ( $\alpha$-MEM; Gibco, Life Technologies, Gaithersburg, MD, USA) supplemented with $10 \%$ fetal bovine serum (FBS; Gibco), $50 \mu \mathrm{g} / \mathrm{ml}$ streptomycin, and $50 \mathrm{U} / \mathrm{ml}$ penicillin. UE7T-13 cells, which are human bone marrow-derived MSCs infected with retroviruses expressing papillomavirus E7 and hTERT to prolong their lifespan $(13,14)$, were purchased from the Health Science Research Resources Bank (JCRB1154, Japan Health Sciences Foundation, Tokyo, Japan) and cultured in $\alpha$-MEM. All cultures were maintained at $37^{\circ} \mathrm{C}$ in a humidified atmosphere of $5 \% \mathrm{CO}_{2}$.

Reverse transcription polymerase chain reaction (RT-PCR). After treatment with $10 \mathrm{ng} / \mathrm{ml} \mathrm{FGF-2} \mathrm{or} 25 \mathrm{ng} / \mathrm{ml}$ TGF- $\beta 1$ for the indicated times, total RNA of SH9 cells was isolated using TRIzol reagent (Invitrogen, Life Technologies, Carlsbad, CA, USA), according to the manufacturer's instructions. One microgram of RNA was reverse-transcribed to first-strand cDNA using a PrimeScript RT reagent kit (Takara Bio, Kyoto, Japan), according to the manufacturer's protocols. Subsequenly, cDNA samples were amplified with specific primer pairs for SDF- $1 \alpha$ and $\beta$-actin (Table I). PCR was performed for 33 cycles at $94^{\circ} \mathrm{C}$ for $1 \mathrm{~min}$, at $56^{\circ} \mathrm{C}$ for $1 \mathrm{~min}$, and at $72^{\circ} \mathrm{C}$ for $1 \mathrm{~min}$. Then $8 \mu \mathrm{l}$ of the PCR product was mixed with $2 \mu \mathrm{l}$ of bromophenol blue-loaded buffer $[0.25 \%$ bromophenol blue, $0.35 \%$ xylene cyanol, $40 \%$ (wt/vol) sucrose in water] and electrophoretically separated in a $1 \%(\mathrm{wt} / \mathrm{vol})$ agarose gel in TAE buffer. After staining with $0.5 \mu \mathrm{g} / \mathrm{ml}$ ethidium bromide, bands of the PCR products were visualized with ultraviolet light and images were captured on polaroid film.

Western blotting. Following treatment with $10 \mathrm{ng} / \mathrm{ml}$ FGF-2 for 7 days, the conditioned medium from the SH9 cell culture was collected to obtain SDF-1 $\alpha$ samples. For Smad2/3 samples, SH9 cells were lysed with RIPA buffer after treatment with TGF- $\beta 1$. Then, $20 \mu 1$ of the conditioned medium or $30 \mu \mathrm{g}$ of the cell lysis sample was dissolved in sodium dodecyl sulfate (SDS) buffer without dithiothreitol (DTT), incubated at $95^{\circ} \mathrm{C}$ for $5 \mathrm{~min}$, electrophoresed on $10 \%$ SDS-polyacrylamide gels, and transferred to a polyvinylidene difluoride (PVDF) membrane (Millipore, Bedford, MA, USA). After being blocked with $5 \%$ skim milk in Tris-buffered saline containing
Table I. Primers used for RT-PCR and real-time PCR.

\begin{tabular}{ll}
\hline Target & \multicolumn{1}{c}{ Oligonucleotide sequence $\left(5^{\prime} \rightarrow 3^{\prime}\right)$} \\
\hline SDF-1 $\alpha$ & F: GAGCCAACGTCAAGCATCTCAA \\
& R: TTTAGCTTCGGGTCAATGCACA \\
Smad7 & F: TCCTGCTGTGCAAAGTGTTC \\
& R: TTGTTGTCCGAATTGAGCTG \\
GAPDH & F: GCACCGTCAAGGCTGAGAAC \\
& R: TGGTGAAGACGCCAGTGGA \\
$\beta$-actin & F: CTGGCACCACACCTTCTACAATG \\
& R: AATGTCACGCACGATTTCCCGC
\end{tabular}

F, forward; R, reverse.

$0.1 \%$ Tween-20 (TBST), the membrane was incubated with mouse anti-human SDF-1 $\alpha$ antibody (R\&D Systems, Abingdon, UK) and subsequently with anti-mouse secondary antibodies (Zymed Laboratories, San Francisco, CA, USA). Specific protein bands were detected by using an enhanced AP conjugate substrate kit (Bio-Rad Laboratories, Hercules, CA, USA), as previously described $(15,16)$.

Real-time PCR. A Thermal Cycler Dice real-time system (Takara Bio) was used for real-time PCR. The cDNAs were amplified with SYBR ${ }^{\circledR}$ Premix Ex Taq and specific primer pairs for SDF-1 $\alpha, \mathrm{Smad} 7$, and glyceraldehyde 3-phosphate dehydrogenase (GAPDH; Table I). The PCR conditions were: $10 \mathrm{sec}$ at $95^{\circ} \mathrm{C}$, followed by 40 cycles of $95^{\circ} \mathrm{C}$ for $5 \mathrm{sec}$ and $60^{\circ} \mathrm{C}$ for $30 \mathrm{sec}$, and finally, $15 \mathrm{sec}$ at $95^{\circ} \mathrm{C}$ and $30 \mathrm{sec}$ at $60^{\circ} \mathrm{C}$.

RNA interference. Transfection of short interfering RNAs (siRNAs) was performed according to the Lipofectamine RNAiMAX protocol (Invitrogen). In brief, SH9 cells were transiently transfected with siRNA against Smad7 (Stealth RNAi, Invitrogen). Forty-eight hours after transfection, the cells were treated with $25 \mathrm{ng} / \mathrm{ml}$ TGF- $\beta 1$ for $0,3,6,12,24$, or 48 h. Then, real-time PCR was performed as described above.

Transwell migration assay. SH9 cells were plated at a density of $2.0 \times 10^{4}$ cells $/ \mathrm{cm}^{2}$ in 24 -well tissue culture plates. When $12 \mathrm{~h}$ later the cells reached confluence, they were treated with $50 \mathrm{ng} / \mathrm{ml}$ TGF- $\beta 1$ for $12 \mathrm{~h}$. Then, the wells were washed thrice with phosphate-buffered saline (PBS), and the medium was replaced with $\alpha$-MEM containing 2\% FBS. UE7T-13 cells were used for the assay. First, $2.0 \times 10^{4}$ UE7T-13 cells were plated on the upper wells of 6.5 -mm-diameter cell culture inserts (BD Biosciences, Bedford, MA, USA) with 8- $\mu \mathrm{m}$-pore filters. Following incubation for $6 \mathrm{~h}$ at $37^{\circ} \mathrm{C}$, the cells that had not migrated were scraped with a cotton swab, and the filters were stained with a Diff-Quik kit (Sysmex, Hyogo, Japan). The number of cells that had migrated to the lower side of the filters was counted under a light microscope (x400 magnification).

Statistical analysis. Data are expressed as the means \pm (SEM) of triplicate experiments and were analyzed by the Student's t-test. $\mathrm{P}<0.01$ indicates a statistically significant difference. 

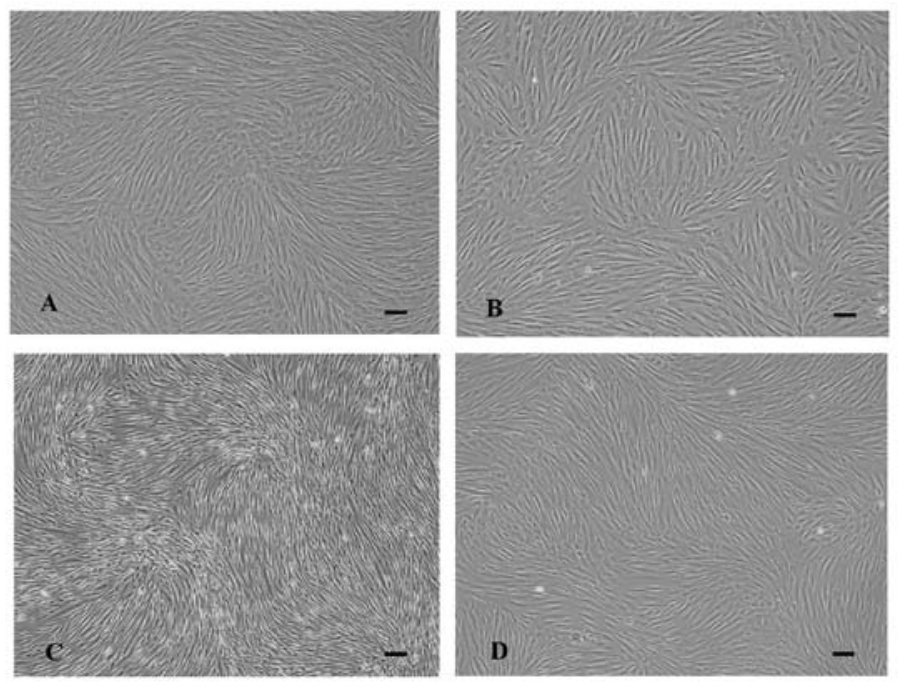

E

$\mathbf{F}$
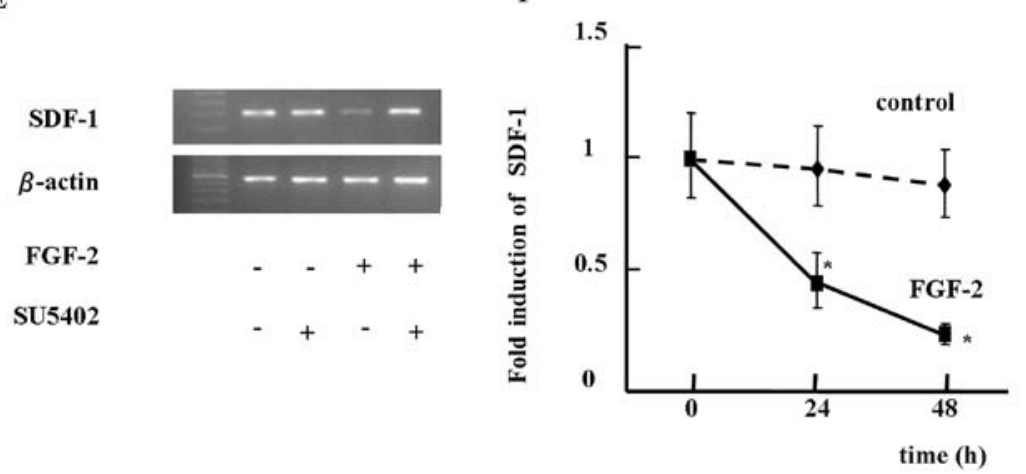

Figure 1. Effects of FGF-2 on the morphology and the SDF-1 $\alpha$ expression of SH9 cells. SH9 cells were cultured in the (A) absence or (C) presence of 10 ng/ $\mathrm{ml} \mathrm{FGF-2} \mathrm{for} 48 \mathrm{~h}$ and treated with (B) SU5402 alone or (D) both FGF-2 and SU5402. (E) Treatment with SU5402 alone and both FGF-2 and SU5402 had no effect on cell morphology and SDF-1 $\alpha$ expression; however, real-time PCR analysis showed that SDF-1 $\alpha$ expression was inhibited following treatment with FGF-2. (F) The inhibition was maintained for $48 \mathrm{~h}$. Scale bar $=100 \mu \mathrm{m}$. Data are the means \pm (SEM) of triplicate experiments; ${ }^{*} \mathrm{P}<0.01$ indicates a statistically significant difference.

\section{Results}

SDF-1a expression in SH9 cells is inhibited by FGF-2 treatment. SH9 cells were treated with $10 \mathrm{ng} / \mathrm{ml} \mathrm{FGF-2} \mathrm{and/or}$ $10 \mu \mathrm{M}$ SU5402 for $48 \mathrm{~h}$, and their morphology was examined. The cells acquired a spindle cell-type morphology after the FGF-2 treatment (Fig. 1C) although the morphology was not different from that of the control cells (Fig. 1A). SDF-1 $\alpha$ mRNA expression decreased after the FGF-2 treatment (Fig. 1E), and the decrease occurred in a time-dependent manner (Fig. 1F).

SDF-1 $\alpha$ production in the SH9 cell culture is reduced by FGF-2 treatment. SDF-1 $\alpha$ protein in the conditioned medium from the SH9 cell culture was detected by western blotting. Treatment with FGF-2 led to a decrease in SDF-1 $\alpha$ production compared with the control condition (Fig. 2A and B), similarly to the significantly decreased mRNA expression (Fig. 1E and F).

TGF- $\beta 1$ induces SDF-1 $\alpha$ expression in SH9 cells via the Smad2/3 pathway. Real-time PCR analysis revealed that TGF- $\beta 1$ treatment for $12 \mathrm{~h}$ induced SDF- $1 \alpha$ expression in SH9 cells (Fig. 3A). SDF-1 $\alpha$ expression did not change following
A
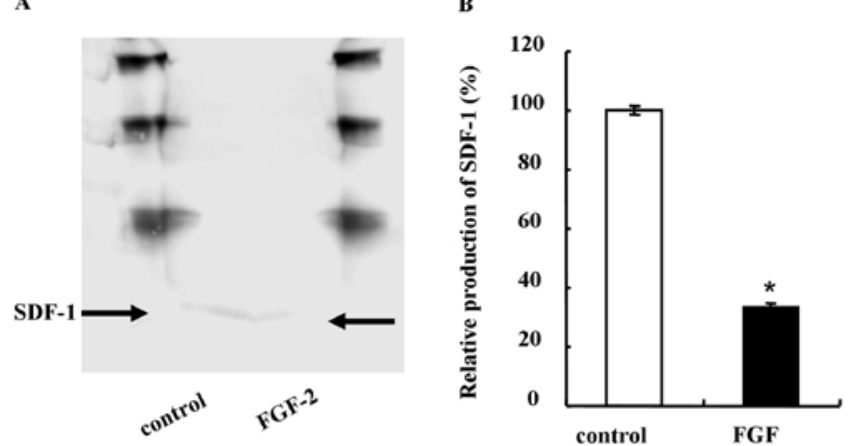

Figure 2. Effect of FGF-2 on SDF-1 $\alpha$ expression in the conditioned medium from the $\mathrm{SH} 9$ cell culture. (A) Western blot analysis showed that the treatment with FGF-2 inhibited SDF-1 $\alpha$ expression. (B) Representative plot of the ratio of SDF-1 $\alpha$ expression in SH9 cells compared to that in the control medium (control values were normalized to $100 \%$ ). Data are the means \pm (SEM) of triplicate experiments; ${ }^{\mathrm{P}}<0.01$ indicates a statistically significant difference.

treatment with $10 \mu \mathrm{M}$ SB431542 alone or with both TGF- $\beta 1$ and SB431542 (Fig. 3A). To confirm this effect of TGF- $\beta 1$, the levels of Smad2/3 and phosphorylated Smad2/3 were evaluated by western blot analysis. Although the total level 
A

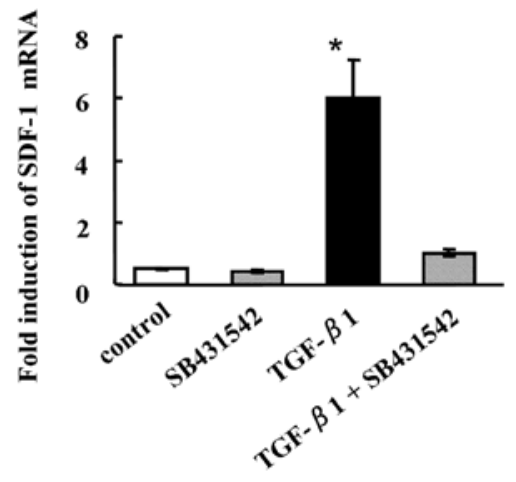

C

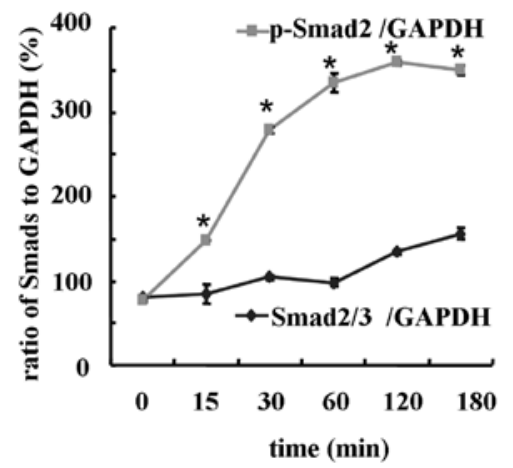

B

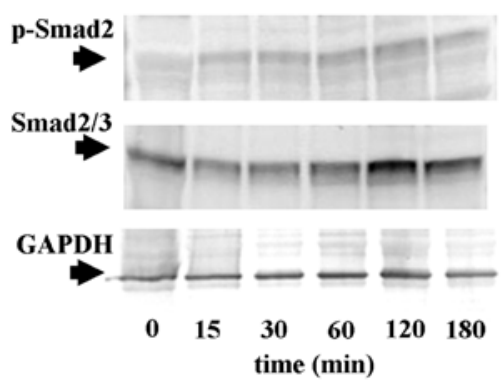

D

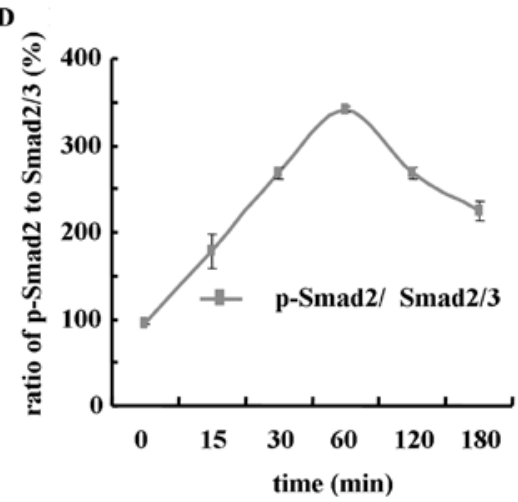

Figure 3. Effects of TGF- $\beta 1$ on SDF- $1 \alpha$ and Smad2/3 in SH9 cells. (A) Real-time PCR analysis showed that treatment with $25 \mathrm{ng} / \mathrm{ml} \mathrm{TGF-} \beta 1$ for $12 \mathrm{~h}$ increased SDF-1 $\alpha$ expression in SH9 cells; however, in the presence of $10 \mu \mathrm{M}$ of SB431542 and both TGF- $\beta 1$ and SB431542, SDF-1 $\alpha$ expression was unaffected. (B-D) Smad2/3 and phosphorylated Smad2 (p-Smad2) expressions were normalized to that of GAPDH and are shown as a percentage of the control (0 h). Data are the means $\pm(\mathrm{SEM})$ of triplicate experiments; ${ }^{2} \mathrm{P}<0.01$ indicates a statistically significant difference.

A

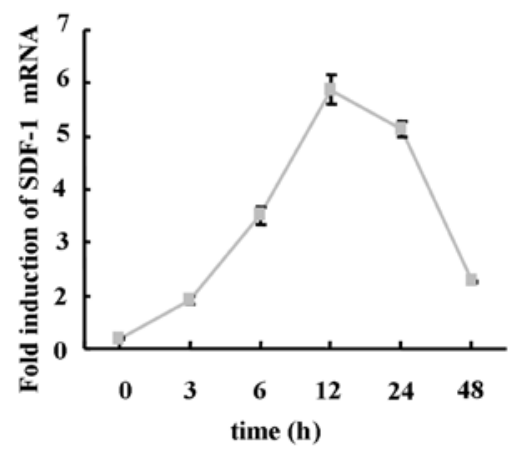

C

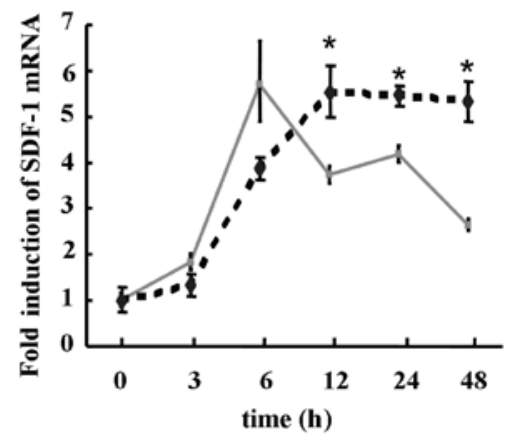

B

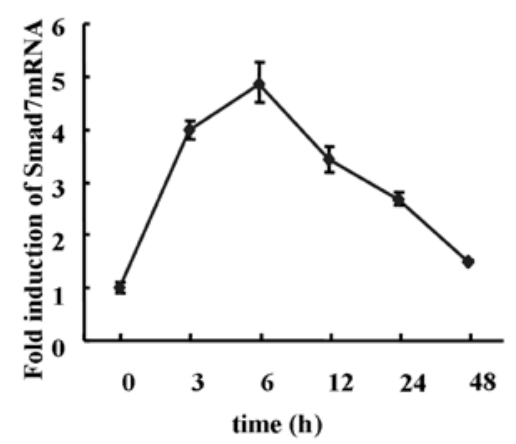

D

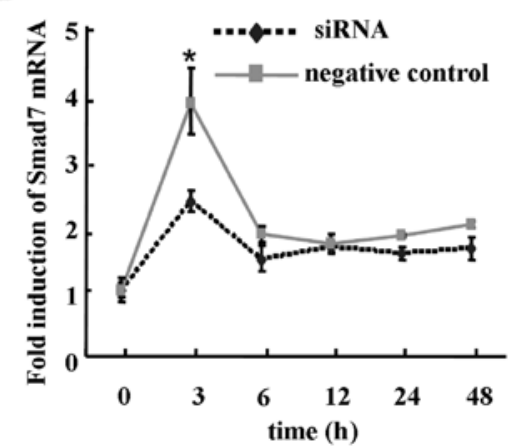

Figure 4. Effects of TGF- $\beta 1$ on (A) SDF-1 $\alpha$ and (B) Smad7 expressions in SH9 cells. SH9 cells were treated with $25 \mathrm{ng} / \mathrm{ml}$ TGF- $\beta 1$ for 3, $6,12,24$, or $48 \mathrm{~h}$. SDF-1 $\alpha$ and Smad7 expressions were normalized to that of GAPDH and are shown as a percentage of the control (0 h). (C) Transfection of siRNA against Smad7 prolonged the TGF- $\beta 1$-induced increase in SDF-1 $\alpha$ expression in SH9 cells; the negative control did not have any effect on the prolonged expression of SDF-1 $\alpha$. (D) Transfection of siRNA against Smad7 suppressed the induction of Smad7 expression. Data are the means \pm (SEM) of triplicate experiments; ${ }^{*} \mathrm{P}<0.01$ indicates a statistically significant difference. 
A

1. SH9 cells were pretreated with TGF- $\beta 1$ for $12 \mathrm{~h}$

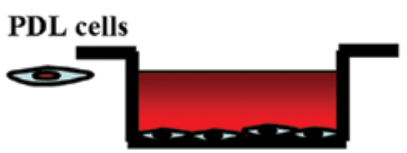

2. After removing the pretreated medium, SH9 cells were washed with PBS; the medium was replaced with $2 \%$ FBS $\alpha$-MEM, and the transwell inserts were placed into the well

3. MSCs were plated on the upper side of the insert

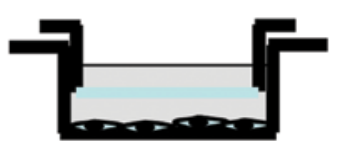

\section{os MSCs}
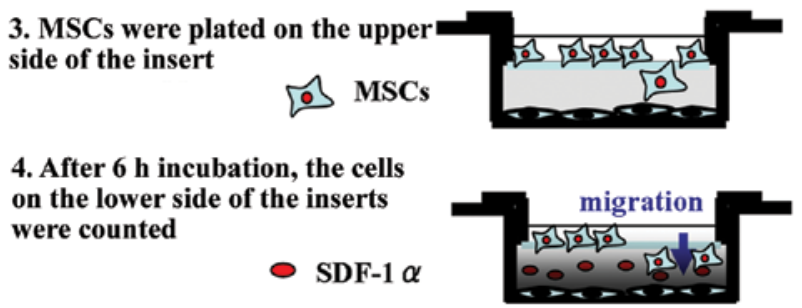

B

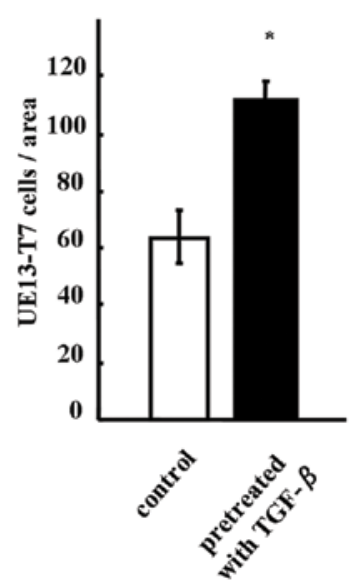

Figure 5. Results of the transwell migration assay show that SH9 cells induce mesenchymal stem cell (MSC) migration. (A) After SH9 cells in 24-well plates were treated with $50 \mathrm{ng} / \mathrm{ml}$ of TGF- $\beta 1$ for $12 \mathrm{~h}$ (step 1), the culture medium in the wells was removed. The cells were washed thrice with PBS, the culture medium was replaced with $\alpha$-MEM containing $2 \%$ FBS, and transwell cell culture inserts were placed into the wells (step 2). UE7T-13 cells were plated on the upper side of the inserts (step 3) and cultured for $6 \mathrm{~h}$ (step 4). Finally, the cells on the lower side of the inserts were counted (B). Data are the means $\pm(\mathrm{SEM})$ of triplicate experiments; ${ }^{*} \mathrm{P}<0.01$ indicates a statistically significant difference.

of Smad2/3 remained the same, the level of phosphorylated $\mathrm{Smad} 2 / 3$ increased and peaked $1 \mathrm{~h}$ after the addition of TGF- $\beta 1$ (Fig. 3B-D). It then decreased $2 \mathrm{~h}$ after the stimulation (Fig. 3D).

TGF- $\beta 1$ induced SDF-1 $\alpha$ and Smad7 expression in SH9 cells. As shown in Fig. 4A, SDF-1 $\alpha$ expression increased until $12 \mathrm{~h}$ and then decreased $48 \mathrm{~h}$ after the treatment with TGF- $\beta 1$. Smad7 expression in SH9 cells also increased by $\sim 5$-fold until $6 \mathrm{~h}$ after the treatment, and then decreased by $48 \mathrm{~h}$ (Fig. 4B).

Transfection of Smad7 siRNA prolongs the induction of SDF-1 $\alpha$ expression in SH9 cells. Transfection of siRNA against Smad7 resulted in prolonged induction of SDF-1 $\alpha$ expression ( $\sim 5$-fold), even after $48 \mathrm{~h}$ following the TGF- $\beta 1$ treatment (Fig. $4 \mathrm{C}$ ), but it suppressed Smad7 expression after $3 \mathrm{~h}$ (Fig. 4D).
UE7T-13 cell migration is induced in the SH9 cell culture treated with TGF- $\beta 1$. Migration of UE7T-13 cells was induced when culture inserts with the cells were placed into wells containing SH9 cells treated with $50 \mathrm{ng} / \mathrm{ml}$ TGF- $\beta 1$ for $12 \mathrm{~h}$ (Fig. 5).

\section{Discussion}

To date, information regarding the expression and regulation of SDF-1 $\alpha$ in periodontal tissues is lacking. To the best of our knowledge, this is the first study to show that the expression of SDF- $1 \alpha$ in PDL cells is regulated by FGF- 2 and TGF- $\beta 1$. FGF-2 inhibited SDF-1 $\alpha$ expression to approximately $10 \%$ of the control level by $48 \mathrm{~h}$, and TGF- $\beta 1$ increased it to approximately 6 -fold of the control level between 6 and $12 \mathrm{~h}$ after treatment. These results suggest that SDF-1 $\alpha$ may play an important role in stem and progenitor cell recruitment and homing to injured sites in the PDL.

SDF- $1 \alpha$ is a small $(8-13 \mathrm{kDa})$ and multifunctional cytokine that is constitutively expressed and secreted by several tissues, including the endothelium and stromal cells (17). Expression of SDF-1 $\alpha$ is upregulated to attract EPCs and MSCs in response to damage of various tissues or organs (8). In the present study, SDF-1 $\alpha$ was constitutively expressed in PDL cells (Fig. 2A) and its expression was modulated by the treatments with FGF-2 and TGF- $\beta 1$. PDL cells may possess regulatory mechanisms to induce and/or suppress various growth factors, including FGF- 2 and TGF- $\beta 1(18,19)$. Since both FGF-2 and TGF- $\beta 1$ are expressed in periodontal tissues by occlusal stimuli and orthodontic force, respectively $(20,21)$, the PDL may maintain itself via the expression of cytokines, such as SDF-1 $\alpha$, FGF-2 and TGF- $\beta 1$.

FGF-2 affects the functional ability of pluripotent progenitor cells or putative stem cells in the PDL. It facilitates the differentiation of these cells to endothelial-like cells $(15,16)$. In the present study, FGF-2 inhibited SDF-1 $\alpha$ expression in SH9 cells. As SU5402 is an FGF receptor (FGFR)-specific tyrosine kinase inhibitor (22), it suppressed the FGF-2-induced morphological changes, and decreased SDF- $1 \alpha$ expression, in SH9 cells (Fig. 1). Therefore, FGF-2 affected SDF-1 $\alpha$ expression via the FGFR pathway. However, whether or not intracellular signaling depends on the inhibition of SDF-1 $\alpha$ expression in SH9 cells remains unclear.

TGF- $\beta 1$ is a member of the TGF- $\beta$ superfamily, which mediates multiple biological processes including bone formation (23). TGF- $\beta 1$ plays a pivotal role in the commitment and differentiation of various cell lineages (23). SB431542 is a small molecule that acts as a specific inhibitor of TGF- $\beta$ type I receptor activin receptor-like kinase 5 (ALK5) (23). Considering that treatment with both TGF- $\beta 1$ and SB431542 suppressed the TGF- $\beta 1$-induced increase in SDF- $1 \alpha$ expression in SH9 cells, it appears that TGF- $\beta 1$ affects SDF- $1 \alpha$ expression via ALK5. Moreover, TGF- $\beta 1$ affects Smad2/3 phosphorylation (Fig. 3). Transient transfection of siRNA against Smad7 prolonged the TGF- $\beta 1$-induced increase in SDF- $1 \alpha$ expression in SH9 cells. These findings showed that the induction of SDF-1 $\alpha$ expression in SH9 cells by treatment with TGF- $\beta 1$ is regulated via the ALK5-Smad2/3 pathway (24). Finally, SH9 cells treated with TGF- $\beta 1$ for $12 \mathrm{~h}$ could induce the migration of MSCs (Fig. 5). 
PDL cells are thought to be responsible for homeostasis and regeneration of periodontal tissues (3-5) following injury or inflammation and mechanical stress by orthodontic treatment. Previous studies have indicated that the PDL contains MSCs (5). Bone marrow-derived MSCs are considered a good source of cells for cell-based therapy (25). However, bone marrow aspiration for MSC extraction is an invasive and painful procedure. In addition, the abundance of these cells as well as their proliferation and differentiation potential decline with increasing age (26). Comparatively, MSC isolation from the PDL of deciduous teeth is noninvasive and economical. These cells can be frozen until required in the clinic. Although MSC isolation from the PDL yields only a small number of cells, these cells can be used in cell-based therapy for tissue regeneration as a source of SDF- $1 \alpha$.

In conclusion, SDF-1 $\alpha$ expression in PDL cells can be regulated by FGF- 2 and TGF- $\beta 1$, and PDL cells treated with TGF- $\beta 1$ can induce the migration of MSCs. These results suggest that periodontal tissue can be maintained by SDF-1 $\alpha$ expression, and PDL cells isolated from deciduous teeth are beneficial tools for cell-based therapy.

\section{Acknowledgements}

This study was supported in part by Grants-in-Aid for Scientific Research (nos. 18592026 and 23592896 to A.I., no. 19791370 to N.C., no. 21390548 to M.M., and nos. 18592239 and 22592296 to T.H.); by grants from the Open Research Project (20092010), the High-Tech Research Project (2008), and the Medical Innovation by Advanced Science and Technology (MIAST); and a Grant-in-Aid for Strategic Medical Science Research Center, all from the Ministry of Education, Culture, Sports, Science and Technology of Japan (2010-2014), as well as by a grant from the Keiryokai Research Foundation (no. 100 to N.C., 2008; no. 103 to A.I.; no. 106 to T.H., 2009).

\section{References}

1. Carnes DL, Maeder CL and Graves DT: Cells with osteoblastic phenotypes can be explanted from human gingiva and periodontal ligament. J Periodontol 68: 701-707, 1997.

2. Freeman E: Periodontium. In: Oral histology: development, structure, and function. 5th ed. Ten Cate AR (ed.) Mosby, St. Louis, pp253-288, 1998.

3. Bartold PM, McCulloch CA, Narayanan AS and Pitaru S: Tissue engineering: a new paradigm for periodontal regeneration based on molecular and cell biology. Periodontol 2000 24: 253-269, 2000.

4. Beertsen W, McCulloch CA and Sodek J: The periodontal ligament: a unique, multifunctional connective tissue. Periodontol 2000 13: 20-40, 1997.

5. Seo BM, Miura M, Gronthos S, Bartold PM, Batouli S, Brahim J, Young M, Robey PG, Wang CY and Shi S: Investigation of multipotent postnatal stem cells from human periodontal ligament. Lancet 364: 149-155, 2004.

6. Wang J, Loberg R and Taichman RS: The pivotal role of CXCL12 (SDF-1)/CXCR4 axis in bone metastasis. Cancer Metastasis Rev 25: 573-587, 2006.

7. Zernecke A, Schober A, Bot I, von Hundelshausen P, Liehn EA, Möpps B, Mericskay M, Gierschik P, Biessen EA and Weber C: SDF-1 $\alpha / C X C R 4$ axis is instrumental in neointimal hyperplasia and recruitment of smooth muscle progenitor cells. Circ Res 96: 784-791, 2005

8. Kucia M, Ratajczak J, Reca R, Janowska-Wieczorek A and Ratajczak MZ: Tissue-specific muscle, neural and liver stem/ progenitor cells reside in the bone marrow, respond to an SDF-1 gradient and are mobilized into peripheral blood during stress and tissue injury. Blood Cells Mol Dis 32: 52-57, 2004.
9. Ratajczak MZ,KuciaM,Reca R,Majka M,Janowska-Wieczorek A and Ratajczak J: Stem cell plasticity revisited: CXCR4-positive cells expressing mRNA for early muscle, liver and neural cells 'hide out' in the bone marrow. Leukemia 18: 29-40, 2004.

10. Murakami S: Periodontal tissue regeneration by signaling molecule(s): what role does basic fibroblast growth factor (FGF-2) have in periodontal therapy? Periodontol 2000 56: 188-208, 2011.

11. Fujii S, Maeda H, Tomokiyo A, Monnouchi S, Hori K, Wada N and Akamine A: Effects of TGF- $\beta 1$ on the proliferation and differentiation of human periodontal ligament cells and a human periodontal ligament stem/progenitor cell line. Cell Tissue Res 342: 233-242, 2010.

12. Hasegawa T, Chosa N, Asakawa T, Yoshimura Y, Ishisaki A and Tanaka M: Establishment of immortalized human periodontal ligament cells derived from deciduous teeth. Int J Mol Med 26: 701-705, 2010.

13. Mori T, Kiyono T, Imabayashi H, Takeda Y, Tsuchiya K, Miyoshi S, Makino H, Matsumoto K, Saito H, Ogawa S, et al: Combination of hTERT and bmi-1, E6, or E7 induces prolongation of the life span of bone marrow stromal cells from an elderly donor without affecting their neurogenic potential. Mol Cell Biol 25: 5183-5195, 2005.

14. Shimomura T, Yoshida Y, Sakabe T, Ishii K, Gonda K, Murai R, Takubo K, Tsuchiya H, Hoshikawa Y, Kurimasa A, et al: Hepatic differentiation of human bone marrow-derived UE7T-13 cells: Effects of cytokines and CCN family gene expression. Hepatol Res 37: 1068-1079, 2007.

15. Hasegawa T, Chosa N, Asakawa T, Yoshimura Y, Asakawa A, Ishisaki A and Tanaka M: Effect of fibroblast growth factor- 2 on periodontal ligament cells derived from human deciduous teeth in vitro. Exp Ther Med 1: 337-341, 2010.

16. Hasegawa T, Chosa N, Asakawa T, Yoshimura Y, Asakawa A, Ishisaki A and Tanaka M: Effect of fibroblast growth factor-2 on dental pulp cells derived from human deciduous teeth in vitro. Exp Ther Med 1: 477-480, 2010.

17. Dar A, Goichberg P, Shinder V, Kalinkovich A, Kollet O, Netzer N, Margalit R, Zsak M, Nagler A, Hardan I, Resnick I, Rot $\mathrm{A}$ and Lapidot T: Chemokine receptor CXCR4-dependent internalization and resecretion of functional chemokine SDF-1 by bone marrow endothelial and stromal cells. Nat Immunol 6: 1038-1046, 2005.

18. Lallier TE and Spencer A: Use of microarrays to find novel regulators of periodontal ligament fibroblast differentiation. Cell Tissue Res 327: 93-109, 2007.

19. Pinkerton MN, Wescott DC, Gaffey BJ, Beggs KT, Milne TJ and Meikle MC: Cultured human periodontal ligament cells constitutively express multiple osteotropic cytokines and growth factors, several of which are responsive to mechanical deformation. J Periodontal Res 43: 343-351, 2008.

20. Boonpratham S, Kanno Z and Soma K: Occlusal stimuli regulate interleukin-1 beta and FGF-2 expression in rat periodontal ligament. J Med Dent Sci 54: 71-77, 2007.

21. Garlet TP, Coelho U, Silva JS and Garlet GP: Cytokine expression pattern in compression and tension sides of the periodontal ligament during orthodontic tooth movement in humans. Eur J Oral Sci 115: 355-362, 2007.

22. Tanaka Y, Okada Y and Hirokawa N: FGF-induced vesicular release of Sonic hedgehog and retinoic acid in leftward nodal flow is critical for left-right determination. Nature 435: 172-177, 2005.

23. Laping NJ, Grygielko E, Mathur A, Butter S, Bomberger J, Tweed C, Martin W, Fornwald J, Lehr R, Harling J, et al: Inhibition of transforming growth factor (TGF)- $\beta 1$-induced extracellular matrix with a novel inhibitor of the TGF- $\beta$ type I receptor kinase activity: SB-431542. Mol Pharmacol 62: 58-64, 2002.

24. Kawabata M, Imamura T, Inoue H, Hanai J-I, Nishihara A, Hanyu A, Takase M, Ishidou Y, Udagawa Y, Oeda E, et al : Intracellular signaling of the TGF- $\beta$ superfamily by Smad proteins. Ann NY Acad Sci 886: 73-82, 1999.

25. Yamada Y, Nakamura S, Ito K, Sugito T, Yoshimi R, Nagasaka T and Ueda M: A feasibility of useful cell-based therapy by bone regeneration with deciduous tooth stem cells, dental pulp stem cells, or bone-marrow-derived mesenchymal stem cells for clinical study using tissue engineering technology. Tissue Eng Part A 16: 1891-1900, 2010.

26. Kern S, Eichler H, Stoeve J, Klüter H and Bieback K: Comparative analysis of mesenchymal stem cells from bone marrow, umbilical cord blood, or adipose tissue. Stem Cells 24: 1294-1301, 2006. 